\title{
MiT Family Translocation Renal Cell Carcinomas
}

\author{
MiT Ailesi Translokasyon Renal Hücreli Karsinomlar
}

\author{
Ayça Tan, Nalan Neşe \\ Celal Bayar University Faculty of Medicine, Department of Pathology, Manisa, Turkey
}

\section{Introduction}

MiT family translocation renal cell carcinomas (RCCS) are particular neoplasms with their clinically aggressive behavior and histopathologically distinctive appearance (1). These tumors tend to occur in young age group and consist of nearly $40 \%$ of pediatric and $1.6-4 \%$ of adult RCCs $(1,2)$.

These tumors are caused by two types of translocations involving TFE3 (transcription factor E3) and TFEB genes which are belong to the Microphtalmia-associated transcriptional factor family (MiT family) $(2,3)$. TFE3 is located on Xp11.2, while TFEB is on chromosome 6. Tumors showing Xp11 translocation are much more common than those involving TFEB translocations. The most common subtypes of gene fusions are ASPSCR1-TFE3 and PRCC-TFE3 $(1,3)$. t(6:11) RCC is the rare form of translocation RCCs which harbors gene fusion among TFEB and MALAT-1 (2). These gene rearrangements result in overexpression of several fusion proteins including TFE3 and TFEB which can be demonstrated with a nuclear labeling by immunohistochemistry as a sensitive and specific diagnostic method for each subtype.

The gross morphology is similar to other RCCs; they do not show a distinct appearance (1). Histopathologically, Xp11 translocation RCC is characterized by papillary structures lined by cells with large, usually clear, sometimes eosinophilic cytoplasm (Figure 1). Immunohistochemically, these tumors are usually negative for epithelial markers [pancytokeratins, epithelial membrane antigen (EMA)], pax-8, and positive for cathepsin $\mathrm{K}$ and TFE3 (Figure 1,inset) (4). The diagnosis of Xp11 translocation RCCs is based on microscopic characteristic findings, nuclear immunostaining with TFE3 and/or genetic analysis. Microscopic appearance of $\mathrm{t}(6 ; 11)$ RCCs is different from Xp11 translocation RCC (2). The most distinctive pattern is composed of nests of larger epithelioid cells admixed with smaller cells grouped around basement membrane material and also entrapped native renal tubules at the periphery
(2). Immunohistochemically, tumour cells show nuclear reactivity for TFEB and cytoplasmic reactivity for cathepsin $\mathrm{K}$ and melanocytic markers (HMB-45 and Melan-A) (2).

The differential diagnosis of MiT family translocation RCCs includes a variety of renal neoplasm demonstrating clear cell and papillary features. Conventional clear cell RCC demonstrates diffuse positive expression with epithelial markers and is negative with melanocytic markers. Papillary RCC is positive for cytokeratin 7 and alphamethylacyl-CoA racemase. In addition, clear cell RCC is characterized by chromosome 3p25 deletion, papillary RCCs by trisomy 7/17. Some of the Xp11 translocation carcinomas include melanin pigment (5). Therefore, epithelioid angiomyolipomas should be considered in the differential diagnosis. Since TFE3 and TFEB gene rearrangements are not present in other neoplasms, fluorescent in situ hybridization can also be useful and helpful in diagnostically challenging cases.

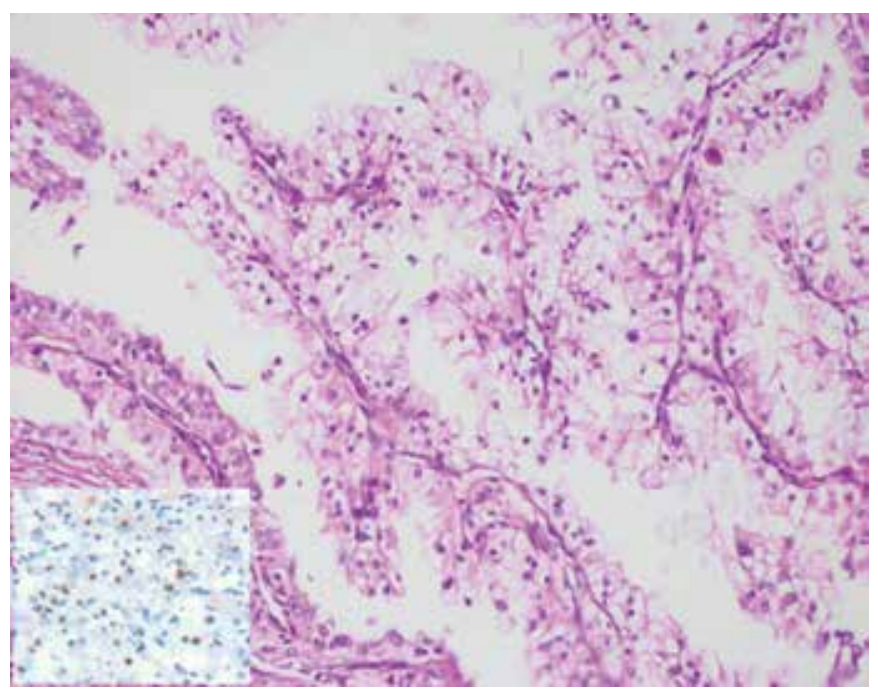

Figure 1. A Xp11 translocation carcinoma having cells with prominent large clear cytoplasms lining papillary structures (x200, HematoxylinctEosin) Inset: TFE3 nuclear positivity (x200)

\section{Correspondence}

Nalan Neşe MD, Celal Bayar University Faculty of Medicine, Department of Pathology, Manisa, Turkey

E-mail: nalannese@hotmail.com Received: 02.08.2016 Accepted: 03.08.2016 
The prognosis of the Xp11 translocation RCCs is similar to clear cell RCCs but worse than PRCCs. $t(6 ; 11)$ RCCs are indolent than Xp11 translocation RCCs. To be aware of these neoplasms on microscope would provide correct diagnosis and predicting of prognosis.

\section{Ethics}

Peer-review: Internal peer-reviewed.

\section{Authorship Contributions}

Surgical and Medical Practices: Ayça Tan, Nalan Neşe, Concept: Ayça Tan, Nalan Neşe, Design: Ayça Tan, Nalan Neşe, Data Collection or Processing: Ayça Tan, Nalan Neşe, Analysis or Interpretation: Ayça Tan, Nalan Neşe, Literature Search: Ayça Tan, Nalan Neşe, Writing: Ayça Tan, Nalan Neşe.

Conflict of Interest: No conflict of interest was declared by the authors.

Financial Disclosure: The authors declared that this study has received no financial support.

\section{Keywords}

Translocation, renal cell carcinomas, MiT family

\section{Anahtar Kelimeler}

Translokasyon, renal hücreli karsinom, MiT ailesi

\section{References}

1. Komai $Y$, Fujiwara $M$, Fujii $Y$, Mukai $H$, Yonese J, Kawakami S, Yamamoto S, Migita $T$, Ishikawa $Y$, Kurata $M$, Nakamura $T$, Fukui I. Adult Xp11 translocation renal cell carcinoma diagnosed by cytogenetics and immunohistochemistry. Clin Cancer Res 2009;15:1170-1176.

2. Smith $N E$, Illei PB, Allaf M, Gonzalez $N$, Morris $K$, Hicks J, Demarzo $A$, Reuter VE, Amin MB, Epstein Jl, Netto GJ, Argani P. t $(6 ; 11)$ renal cell carcinoma (RCC): expanded immunohistochemical profile emphasizing novel RCC markers and report of 10 new genetically confirmed cases. Am J Surg Pathol 2014;38:604-614.

3. Argani $P$, Antonescu $C R$, Illei $P B$, Lui MY, Timmons $C F$, Newbury $R$, Reuter $V E$, Garvin AJ, Perez-Atayde AR, Fletcher JA, Beckwith JB, Bridge $J A$, Ladanyi M. Primary renal neoplasms with the ASPL-TFE3 gene fusion of alveolar soft part sarcoma: a distinctive tumor entity previously included among renal cell carcinomas of children and adolescents. Am J Pathol 2001;159:179-192.

4. Argani P, Hicks J, De Marzo AM, Albadine R, Illei PB, Ladanyi M, Reuter VE, Netto GJ. Xp11 translocation renal cell carcinoma (RCC): extended immunohistochemical profile emphasizing novel RCC markers. Am J Surg Pathol 2010;34:1295-1303.

5. Argani P, Aulmann S, Karanjawala Z, Fraser RB, Ladanyi M, Rodriguez MM. Melanotic Xp11 translocation renal cancers: a distinctive neoplasm with overlapping features of PEComa, carcinoma, and melanoma. Am J Surg Pathol 2009;33:609-619. 